[Pre-publication version of: Kynes, Will. "Morality and Mortality: The Dialogical Interpretation of Psalm 90 in the Book of Job." Journal for the Study of the Old Testament (forthcoming).]

Morality and Mortality:

The Dialogical Interpretation of Psalm 90 in the Book of Job

\begin{abstract}
This article identifies dialogical interpretation in Job as a form of aggadic inner-biblical exegesis. Job and the friends frequently attack each other through allusions to each other's words. This interpretive dispute spreads into their allusions to other texts, which are drawn into the dialogue and caught up in the conflict. Job and the friends frequently interpret these texts differently, capitalizing on their tensions and manipulating them into weapons in their debate. Ps. 90, with its ambiguous presentation of specific and universal referents, God as deliverer and destroyer, and human transience as punishment and grounds for pity, becomes one of these weapons. While the friends appeal to the psalm to urge Job from complaint to confession, Job incorporates it into his divine confrontation. By depicting this contentious dialectic between his characters' interpretations, the Job poet produces a meta-interpretation that represents the psalm's conflicted advocation for sufferers courageously to confront God.
\end{abstract}

Keywords: Job, Psalm 90, allusion, aggadic exegesis, inner-biblical exegesis, intertextuality

Following the publication of Michael Fishbane's Biblical Interpretation in Ancient Israel, biblical scholars have increasingly recognized the degree to which their interpretation is, in fact, meta-interpretation. Rather than merely an inert object to be interpreted, the biblical text has emerged as an active interpretive agent. Fishbane's comprehensive study hardly exhausted the topic, however. It maps the surface of a terrain whose depths are yet to be fully mined. Of the four broad types of 'exegesis' Fishbane describes (scribal comments and 
corrections, legal, aggadic, and mantological), in this article, I unearth the Job poet's distinctive development of the third. According to Fishbane, aggadic exegesis is 'not content to supplement gaps in the traditum, but characteristically draws forth latent and unsuspected meanings from it. ${ }^{1}$ To extract these meanings, the Job poet depicts conflicting biblical interpretations in the dialogue between Job and the friends, thereby producing his own meta-interpretation. The use of Ps. 90 in the book of Job is a valuable example of this dialogical aggadic exegetical technique.

Fishbane's work traces the continuity between inner-biblical interpretation and later rabbinic exegesis. ${ }^{2}$ The Job poet's dialogical interpretation of earlier texts is an instance of this phenomenon. Midrashic texts, such as the Mekilta on Exodus, frequently juxtapose contradictory interpretations, each which attempts to clarify biblical ambiguities, but which cumulatively 'focus on the ambiguity and the possibilities for making meaning out of it' ${ }^{3}$ For

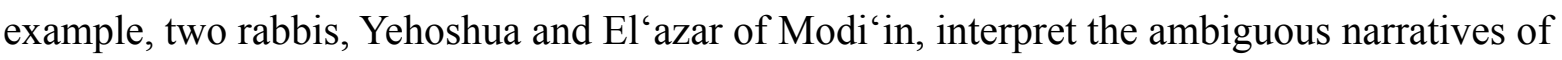
Mara and manna provision (Exod. 15.22-26; 16.2-36) differently to support their contrasting views of Israel's faithfulness in the wilderness. ${ }^{4}$ The midrash dialectically reveals the texts' ambiguity through both rabbis' attempts to eradicate it.

\footnotetext{
${ }^{1}$ Michael Fishbane, Biblical Interpretation in Ancient Israel (Oxford: Clarendon,
} 1985), p. 283.

${ }^{2}$ Ibid., p. 527.

${ }^{3}$ Daniel Boyarin, Intertextuality and the Reading of Midrash (Indiana Studies in Biblical Literature; Bloomington: Indiana University Press, 1990), p. 58.

${ }^{4}$ Ibid., pp. 57-79. 
The Job poet relies heavily on allusions, intentional implicit references to earlier utterances, as a rhetorical tool to advance his message. ${ }^{5}$ Allusions between the speeches in the dialogue demonstrate both the author's method of allusion, which frequently involves slight adaptations, and his expectation that readers would be able to recognize these implicit connections. ${ }^{6}$ For example, Job's question in 21.17 , 'How often is the lamp of the wicked put

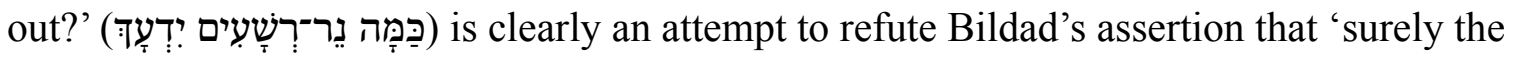

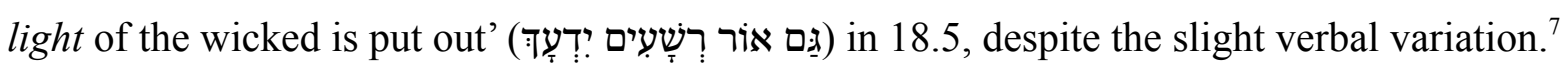
The Job poet did not feel constrained to allude to earlier texts exactly, and thus differences with a source text, though they make allusions more difficult to recognize, are not sufficient

\footnotetext{
${ }^{5}$ For this definition of allusion, distinguishing it from quotation as intentional explicit reference and echo as unintentional implicit reference, see Will Kynes, My Psalm Has Turned into Weeping: Job's Dialogue with the Psalms (BZAW, 437; Berlin: de Gruyter, 2012), pp. 30-33.

${ }^{6}$ See Robert Gordis, The Book of Job: Commentary, New Translation, and Special Studies (Moreshet, 2; New York: Jewish Theological Seminary of America, 1978), pp. 185-88; Michael A. Lyons, “I also could talk as you do' (Job 16:4): The Function of Intratextual Quotation and Allusion in Job', in Katharine Dell and Will Kynes (eds.), Reading Job Intertextually (LHBOTS, 574; New York: Bloomsbury T\&T Clark, 2013).

${ }^{7}$ Though for ease of presentation, I will refer to Job and his friends alluding to and even interpreting texts, the author is ultimately responsible for portraying the characters' interaction with earlier texts. Unless otherwise noted, all English translations of biblical passages are from the NRSV.
} 
arguments against their existence but actually in keeping with the author's allusive technique. $^{8}$

In some cases, minor modifications may simply result from poetic license, though the alternation between 'light' (אור) and 'lamp' (נר) in these two passages appears to point the reader to the common allusion both characters are making to Prov. 13.9, which uses both terms: 'The light of the righteous rejoices, but the lamp of the wicked goes out' (אוֹר־צַדִיקִים

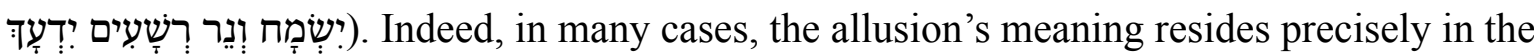
alteration, as the characters reappropriate earlier expressions for their argumentative purposes, as in Job's transformation of Bildad's confident assertion into a cynical question above. $^{9}$

The clearest and most commonly cited instance of the author's intentional alteration of his source text is Job's 'bitter parody' of Ps. 8.5 [4] in Job 7.17-18. In the midst of his hymn praising God for the honor the deity bestows on comparatively insignificant human

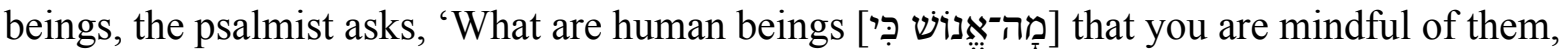

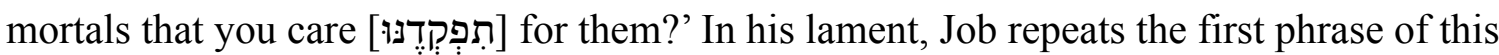
question and imitates its basic structure but reverses the significance of the ambivalent term

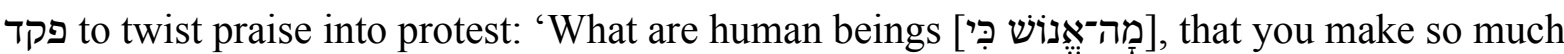

${ }^{8}$ The difficulty of catching the implied connections within the book's allusive poetry may have been intended in an ancient Semitic context that delighted in riddles (Gordis, Job, pp. 193-96, 201).

${ }^{9}$ See also Job's allusion to Job 18.2a in 19.2 (Michael Cheney, Dust, Wind and Agony: Character, Speech and Genre in Job [ConBOT, 36; Stockholm: Almqvist \& Wiksell International, 1994], pp. 120-21). 


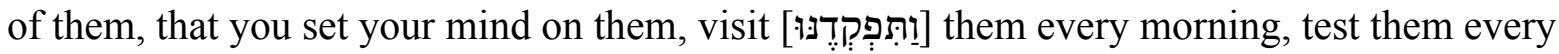
moment?'

The implicit nature of allusions means their existence can rarely be definitively proven. Reference to a common tradition or a reversed order of dependence have both been suggested to dismiss the 'scholarly commonplace' of Job's allusion to Ps. $8 .{ }^{10}$ However, these objections have not taken into account the full extent of the lexical similarity between the passages, which includes several further elements, the parodistic relationship between them, which is unlikely to be reversed (alluding to Job's lament would undercut the psalmist's praise), and the recurring language from this passage in Job $(15.14-16 ; 19.9 ; 25.5-6)$, which incorporate additional aspects of the psalm. ${ }^{11}$ Additionally, setting a common formula against a direct allusion is a false dichotomy; further similarities between the passages beyond the mere formulaic language could indicate that an author is alluding to a particular instance of a formula as employed in a specific text.

Viewed as a whole, the recurrence of Ps. 8 in Job does more than provide the cumulative evidence that arguments for allusion often require. ${ }^{12}$ It also demonstrates the Job poet's

${ }^{10}$ See Raymond C. Van Leeuwen, 'Psalm 8.5 and Job 7.17-18: A Mistaken Scholarly Commonplace?', in P. M. Michèle Daviau et al. (eds.), The World of the Aramaeans I: Biblical Studies in Honour of Paul-Eugène Dion (JSOTSup, 324; Sheffield: Sheffield Academic Press, 2001); cf. Lyle Eslinger, 'Inner-Biblical Exegesis and Inner-Biblical Allusion: The Question of Category', VT 42 (1992), p. 55; Helmut Schnieringer, Psalm 8: Text-GestaltBedeutung (ÄAT, 59; Wiesbaden: Harrassowitz, 2004), pp. 432-33.

${ }^{11}$ For details, see Kynes, My Psalm, pp. 63-79.

${ }^{12}$ See Benjamin D. Sommer, A Prophet Reads Scripture: Allusion in Isaiah 40-66 (Stanford, CA: Stanford University Press, 1998), p. 35. 
dialogical interpretive approach. The question about human worth in Ps. 8.5 [4] is intentionally ambivalent in its context. The rhetorical force of the positive answer in the following verses is dependent on the initial negative response anticipated by the previous description of the relative majesty of God's heavenly handiwork. Though Job transforms this amazement into accusation, his protest is built on the psalm's positive presentation of human worth, which authorizes him to expect more from God. ${ }^{13}$ However, in order to silence Job's impropriety, Eliphaz draws on the psalmist's acknowledgment of divine superiority. He asks, 'What are

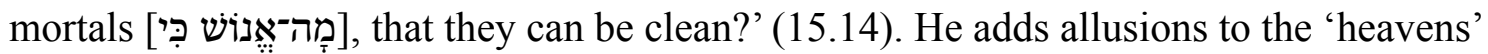
(שמים) and 'heavenly beings' (אלהים) in Ps. 8.4, 6 [3, 5], not to accentuate the wonder of divine condescension, as the psalmist had, but to inquire how Job could hope to expect God's care if even 'his holy ones' (שדשיו) and the 'heavens' (שמים) 'are not clean in his sight' (15.15). Job retorts, using the psalmist's praise for God's 'crowning' (עטר) of humanity with 'glory' (כבד) (5]) to accuse the deity of stripping his 'glory' (כבד) and 'crown' (עטרת) from him (Job 19.9). Bildad then echoes Eliphaz's response and draws on further language from Ps. 8.4 [3] to ask how Job can expect divine favor when even the 'moon' (ירח) and 'stars' (כוכבים), which the psalmist praises as God's handiwork, 'are not pure in his sight' (Job 25.5). Drawing on the parallel terms for humanity used by the psalmist in the same

${ }^{13}$ Christian Frevel, “Eine kleine Theologie der Menschenwürde': Ps 8 und seine Rezeption im Buch Ijob', in Frank-Lothar Hossfeld and Ludger Schwienhorst-Schönberger (eds.), Das Manna fällt auch heute noch: Beiträge zur Geschichte und Theologie des Alten, Ersten Testaments (HBS; Freiburg: Herder, 2004), p. 261.

${ }^{14}$ For this translation of אלהים here, see Hans-Joachim Kraus, Psalms: A Continental Commentary (2 vols.; trans. Hilton C. Oswald; Minneapolis: Fortress Press, 1993), I, p. 183. 
order, Bildad concludes, 'How much less a mortal [אנוש], who is a maggot, and a human being [בץ־אדם], who is a worm!' (Job 25.6).

As in the competing allusions to Prov. 13.9 in Job 18.5 and 21.17 above, these allusions to Ps. 8 within the book's dialogue integrate intratextual and intertextual reference into a dialogical intertextuality in which Job and the friends both allude to the same text. This adds a hermeneutical component to the dialogue, as the disputants draw on tensions and ambiguities within the psalm, interpreting it in different ways in order to support their opposing views on Job's suffering. The same technique is also evident in the book's recurrent allusions to Pss. $1,8,73,107$, and $139 .{ }^{15}$ For each psalm that the Job poet subjects to this sort of dialogical interpretation, the competing interpretations magnify a latent tension within it, with Job primarily parodying the positive pole to call God to account for his divergence from the psalmic norm and the friends repeatedly proof-texting from the negative pole to put Job in his place. $^{16}$

Potential allusions to Ps. 90 in the dialogue, I will argue, correspond to this same interpretive approach. The dates of both texts, to the degree that they can be determined, do not exclude the possibility that Job is the later text since scholars generally consider both works postexilic. ${ }^{17}$ Lacking this external evidence for order of dependence, the determination

${ }^{15}$ Kynes, My Psalm.

${ }^{16}$ Ibid., pp. 183-87.

${ }^{17}$ For Job, see, e.g., Georg Fohrer, Das Buch Hiob (KAT, 16; Gütersloh: Gütersloher Verlagshaus Gerd Mohn, 1963), p. 42; Robert Gordis, The Book of God and Man: A Study of Job (Chicago: University of Chicago Press, 1978), p. 216; C. L. Seow, Job 1-21: Interpretation and Commentary (Illuminations; Grand Rapids, MI: Eerdmans, 2013), pp. 39-45. For Ps. 90, see, e.g., Marvin E. Tate, Psalms 51-100 (WBC, 20; Dallas: Word Books, 1990), p. 438; 
must rely on a comparison of the texts themselves. As will be demonstrated below, reading these parallels as the Job poet's allusions to the psalm offers a more plausible explanation of their rhetorical purpose. The psalmist has little to gain from alluding to the shared imagery as it appears in the dialogue, where Job divorces it from hope and the friends wed it with wickedness, but both Job and the friends can capitalize on the tensions in the psalm to argue their case.

\section{Psalm 90}

The tension in Ps. 90 is built into its very structure, with the psalmist's 'pessimistic realism' in vv. 13-17 at odds with 'the optimistic background of his petition' in vv. $1-12 .{ }^{18}$ This leads interpreters to question the psalm's original unity, creating a dialogue between these different voices within the psalm itself. ${ }^{19}$ However, this tension in the psalm is unavoidable and multi-

Thomas Krüger, 'Psalm 90 und die "Vergänglichkeit des Menschen”, Biblica 75 (1994), p. 211; Christine Forster, Begrenztes Leben als Herausforderung: Das Vergänglichkeitsmotiv in weisheitlichen Psalmen (Zürich: Pano, 2000), pp. 183-84; Richard J. Clifford, 'Psalm 90: Wisdom Meditation or Communal Lament?', in Peter W. Flint and Patrick D. Miller, Jr. (eds.), The Book of Psalms: Composition and Reception (VTSup 99; Leiden: Brill, 2005), pp. 200, 204 n. 33; Frank-Lothar Hossfeld and Erich Zenger, Psalms 2: A Commentary on Psalms 51-100 (Hermeneia; trans. Linda M. Maloney; Minneapolis: Fortress Press, 2005), p. 421.

${ }^{18}$ Artur Weiser, The Psalms: A Commentary (OTL; Philadelphia: Westminster Press, 1962), p. 601.

${ }^{19}$ Many have followed Hermann Gunkel, who suggests vv. 13-17 are a lament added to the original psalm in vv. 1-12 (Die Psalmen [Göttingen: Vandenhoeck \& Ruprecht, 1929], 
faceted, appearing not only in the relations between the psalm's sections but also in ambivalent imagery throughout. ${ }^{20}$ Indeed, "deliberate ambiguity" is a frequent feature of the Psalms, particularly in regard to weighty theological issues. ${ }^{21}$ Further, dissecting the psalm may provide a historical explanation behind its current form, but it does not explain the theological perspective that would inspire them to be united, which may reflect a recognition of the tensions 'in the nature of faith itself., 22

Tension exists in the psalm between its possible specific or universal referent. ${ }^{23}$ Westermann considers vv. 3-12 an expansion that transforms a national lament into a general mortality lament, widening the people's destiny into that of mankind, with the switch from the first-person plural pronoun (v. 1) to third-person references to humanity (vv. 3, 5) signal-

pp. 397, 399). See Krüger, 'Psalm 90’, p. 192 n. 4. Thematically, Claus Westermann argues that vv. 13-17 are the goal of the psalm and thus should not be considered secondary. Instead, he argues vv. 3-12 are a latter addition ('Der 90. Psalm: Forschung am Alten Testament', Theologische Bücherei 24 [1964], pp. 344, 349).

${ }^{20}$ See Krüger, 'Psalm 90', p. 205.

${ }^{21}$ Paul R. Raabe, 'Deliberate Ambiguity in the Psalter', JBL 110 (1991), pp. 213-27.

${ }^{22}$ Weiser, Psalms, p. 601. For structural arguments for the psalm's unity, see Stefan Schreiner, 'Erwägungen zur Struktur des 90. Psalms', Biblica 59 (1978), pp. 80-90; Pierre Auffret, 'Essai sur la structure littéraire du Psaume 90', Biblica 61 (1980), pp. 262-76.

${ }^{23}$ See Renate Brandscheidt, “"Unsere Tage zu zählen, so lehre du” (Psalm 90,12): literarische Gestalt, theologische Aussage und Stellung des 90. Psalms im vierten Psalmenbuch', Trierer theologische Zeitschrift 113 (2004), p. 31. 
ing this shift. ${ }^{24}$ However, the first-person plural returns in v. 7 and remains, repeated in nearly every subsequent verse. Now, however, the referent is unclear. Is the experience of the 'we' here specific to the people who have made the Lord their 'dwelling place' (v. 1) and refer to themselves as the Lord's 'servants' (vv. 13, 16) or does it include all humanity? Based primarily on the change in verb tense from the imperfect in vv. 3-6 to the perfect in vv. 7-9, Thomas Krüger argues that the latter verses describe the speaker's actual situation, and thus the psalm laments not general human transience but a special situation that the community is now suffering due to God's wrath against its $\sin .{ }^{25}$ Erich Zenger, though, represents the majority of interpreters when he rejects this thesis as 'contrary ... to the overall course of the psalm. ${ }^{26}$ However, this interpretive dispute is built into the psalm itself as it interweaves national and universal language.

A second related theological tension is the psalm's presentation of God as both destroyer and deliverer, as it careens between 'the somber portrayal of the brevity of life and its waywardness under the wrath of God' and 'the joy and majestic vision of the saving work of Yahweh for his servants. ${ }^{27}$ The psalm's ambivalent language exacerbates this tension. For example, in v. 1, the word used to describe God as a 'dwelling place' or 'refuge', מעון, may also refer to a wild beast's lair (Job 38.40; Amos 3.4). ${ }^{28}$ That word and the other term of

\footnotetext{
${ }^{24}$ Westermann, 'Der 90. Psalm', pp. 344, 346.

${ }^{25}$ Krüger, 'Psalm 90', pp. 201-2. See also, Forster, Vergänglichkeitsmotiv, pp. 186,
} 199.

\footnotetext{
${ }^{26}$ Hossfeld and Zenger, Psalms 2, p. 417.

${ }^{27}$ Tate, Psalms, p. 444.

${ }^{28}$ Walter Harrelson argues this word is 'deliberately chosen' for this reason ('A Medi-
} 
praise from v. 2, 'everlasting' (עולם), are punned in v. 8 with similar sounding words describing what God sees in the supplicants, their 'iniquities' (עון) and 'secret sins' (עלם). psalm's first verse also raises the question of why humanity needs this refuge, since in the rest of the psalm, the only threat mentioned is the wrath of God. ${ }^{30}$ Further, the first half of $v$. 3, which speaks of God turning (שוב) humanity to 'dust', may allude to Gen. 3.19, or, at least, the tradition recorded there. However, it replaces the word for 'dust' there (עפר) with one derived from the verb דכא ('to crush') and changes the main verb, 'return' (שוב), from qal to hiphil, thereby accentuating the destructive aspect of God's relation to humanity (cf. Isa. $53.5,10) .^{31}$

This continues throughout vv. 3-11, where 'God himself is the cause of bleak transience. ${ }^{32}$ However, Stefan Schreiner, who divides the psalm after v. 11, claims the final ver-

tation on the Wrath of God: Psalm 90', in Arthur L. Merrill and Thomas W. Overholt (eds.), Scripture in History and Theology: FS J. C. Rylaarsdam (PTMS, 17; Pittsburgh: Pickwick Press, 1977), pp. 185-86). See also Forster, Vergänglichkeitsmotiv, p. 171.

${ }^{29}$ William J. Urbrock, 'Mortal and Miserable Man: A Form-critical Investigation of Psalm 90', in Society of Biblical Literature 1974 Seminar Papers, 2 vols., (SBLSP, 6; Cambridge, MA: SBL, 1974), p. 1:12.

${ }^{30}$ Werner H. Schmidt, “Der du die Menschen lässet sterben’: Exegetische Anmerkungen zu Ps 90', in Frank Crüsemann et al. (eds.), Was ist der Mensch...? Beiträge zur Anthropologie des Alten Testaments (Munich: Kaiser, 1992), p. 121.

${ }^{31}$ Forster, Vergänglichkeitsmotiv, pp. 176-77; Hossfeld and Zenger, Psalms 2, p. 422.

${ }^{32}$ Gerhard von Rad, 'Psalm 90', in God at Work in Israel, trans. John H. Marks (Nashville: Abingdon, 1980), p. 214. 
ses (vv. 12-17) deliberately repeat words and concepts from the first section to temper this threatening view of God, providing the congregation with hope through a series of antithetical parallels. ${ }^{33}$ Urbrock notes similar correspondences, such as, 'If mankind lasts but a morning ([בבקר], v. 6), in the morning ([בבקר], v. 14) it expects God's mercy. While the human family soon returns ([שוב], v. 3) to the dust, God may return ([שוב], v. 13) sooner to take pity. ${ }^{34}$ Thus, he concludes, 'In the very act of praying such a National Lament the hope of the people is rekindled. ${ }^{35}$

The function of the brevity of human life in the psalm in light of this dual presentation of God's relation to humanity creates a third tension. ${ }^{36}$ Does the psalm accept the transient conditio humana as resulting from sin or protest against it? ${ }^{37}$ The psalm depicts human transience as the effect of God's wrath in vv. $3-12 .{ }^{38}$ But this transience also grounds the appeal

${ }^{33}$ Schreiner, 'Struktur des 90. Psalms' Thus, vv. 3 corresponds with 13; vv. 5-7 with v. 14; vv. 8-9 with v. 15 ; v. 10 with vv. 16-17; vv. 11 with 12 . Similarly, Auffret, 'Psaume 90', pp. $270-72$.

${ }^{34}$ Urbrock, 'Mortal and Miserable Man', I, p. 15.

${ }^{35}$ Ibid., p. 15.

${ }^{36}$ See Westermann, 'Der 90. Psalm', p. 349.

${ }^{37}$ Krüger, 'Psalm 90', p. 191. Similarly, Clifford, 'Psalm 90', p. 190.

${ }^{38}$ Against the consensus, Clifford claims the two topoi of brevity of life and wrath are not logically linked (Ibid., p. 199). The themes, however, are too closely intertwined in vv. 9-12 to be separated. 
for divine mercy in vv. $13-17 .{ }^{39}$ Sigmund Mowinckel overcomes this dilemma by claiming the psalm is a prayer for the eternal God 'to have mercy upon his congregation which consists of such short-lived people. ${ }^{40}$ However, this only raises another question, if God is the cause of this condition, why would the supplicants expect God to change it? If YHWH has changed from protector to punisher, on what basis does the psalmist think the deity will change once more $?^{41}$ The last petition for God to prosper the work of the community's hands (v. 17) 'seems to fly against the claims of the first half of the psalm', demonstrating either 'pitiful, stubborn defiance in the face of theological reality' or hope in 'the natural outflow of God's majesty when that majesty is articulated as covenant faithfulness. ${ }^{42}$

The psalm's first verse supports the latter explanation. Richard Clifford claims the psalm 'refuses to believe that God would not live up to his name as the refuge of his people.' When the psalm declares God's protective presence 'in all generations', Clifford writes,

${ }^{39}$ Forster, Vergänglichkeitsmotiv, p. 199.

${ }^{40}$ Sigmund Mowinckel, The Psalms in Israel's Worship (2 vols.; trans. D. R. ApThomas; Oxford: Basil Blackwell, 1962), II, p. 75. Human ephemerality is a motif often found in laments to increase the petition's effectiveness (e.g. Pss. 6.6; 30.10; 39.5, 6; 88.11; 89.48; 109.23). See Hermann Gunkel and Joachim Begrich, Introduction to Psalms: The Genres of the Religious Lyric of Israel (Mercer Library of Biblical Studies; Macon, GA: Mercer University Press, 1998), p. 174.

${ }^{41}$ John Goldingay, Psalms (3 vols.; BCOTWP; Grand Rapids, MI: Baker Academic, 2006), III, p. 36.

${ }^{42}$ Walter Brueggemann, The Message of the Psalms: A Theological Commentary (Augsburg Old Testament Studies; Minneapolis: Augsburg, 1984), p. 115. 
'Reflecting on God's history with this people, it insists that God live up to promises made to their ancestors and bless these creatures of a moment with prosperity. ${ }^{43}$ The psalmist holds throughout to the initial claim of YHWH's abiding constancy in vv. 1-2, which is 'the overriding religious reality of the psalm' undiminished by the negativity and resignation in vv. 3-11. ${ }^{44}$ Humans may fade and whither, but, the psalmist believes, God's covenant character endures. Like Moses, to whom the psalm is ascribed, and to whose intercession to save the people from divine wrathful destruction the psalm alludes (v. 13; cf. Exod. 32.12), the psalm calls its readers to challenge God based on his promises (cf. Exod. 32.13). ${ }^{45}$ Doing so would put them in a long line of faithful servants of God who have had the faith and courage to stand up to the deity based on God's self-disclosure, including not only Moses, but also Abraham (Gen. 18) and Job, 'the prime exemplar of the faithful servant who demands a hearing from God. ${ }^{46}$
${ }^{43}$ Clifford, 'Psalm 90', p. 205.
${ }^{44}$ Brueggemann, Psalms, pp. 112, 115. Similarly, Mowinckel, Psalms, I, pp. 24, $220-21$.

${ }^{45}$ Samuel E. Balentine, 'Turn, O Lord! How Long?', Review and Expositor 100 (2003), pp. 466-72. The Targum draws on this connection both in its superscription and its translation of v. 13. See David M. Stec, The Targum of Psalms (ArBib, 16; Collegeville, MN: Liturgical Press, 2004), p. 174.

${ }^{46}$ Balentine, 'Turn, O Lord!', pp. 476-77. For Moses as the 'key’ to the psalm's interpretation, see Robert Abelava, Le motif de la fragilité de l'homme dans le Psaume 90: Une analyse sémantique et contextuelle (Altes Testament und Moderne, 26; Zurich: Lit, 2013), pp. $145-48$. 
Psalm 90 in Job

Facing the inexplicable wrath of God, then, Job could naturally see his experience in Ps. 90, and he proves himself a good reader of the psalm by following its call to confront the deity with divine self-revelation. ${ }^{47}$ The psalm, however, only arrives at the pleading, even protesting interrogative and imperative which predominates in vv. 13-17 after the declarative depiction of the conditio humana sub ira Dei in vv. 3-12. In this section, the friends can also hear their own sentiments expressed, though they reveal themselves less adept readers by transforming the psalm into a defense of divine retribution rather than a plea for divine deliverance. Through Job's dialogue with his friends, therefore, the Job poet externalizes and accentuates the psalm's internal debate. Following this dialogical interpretation involves tracing two intermingled streams of allusions, intertextual ones to the psalm and intratextual ones within the dialogue, as they flow together, strengthening one another, into a roiling debate over Job's status and the psalm's meaning.

Eliphaz (chs. 4-5)

This dialogical interpretation begins in Eliphaz's first speech, which at first seems to assume Job's piety (vv. 3-6), but soon introduces a retributive doctrine that implicitly groups Job with the wicked due to his suffering. The psalmist laments that the human lifespan 'is only toil [עמל] and trouble [און].' Eliphaz claims, 'As I have seen, those who plow iniquity [און] and

${ }^{47}$ For the author(s) of Job as 'readers' of the Psalms, who employ them as 'rhetorical, sapiential and theological foundation' for their argumentation in light of a similar use of Ps. 104, see Christian Frevel, 'Telling the Secrets of Wisdom: The Use of Psalm 104 in the Book of Job', in Katharine Dell and Will Kynes (eds.), Reading Job Intertextually (LHBOTS, 574; New York: Bloomsbury T\&T Clark, 2013), p. 167. 
sow trouble [עמל] reap the same' (v. 8). Though the pairing of 'iniquity' (און) and 'trouble' (עמל), which appears eleven times in the Hebrew Bible, may have been a fixed form in Hebrew poetry, its use in Ps. 90.10 creates a suggestive parallel with Eliphaz's words. ${ }^{48}$ This connection is bolstered by the next verse in Job, where Eliphaz asserts, 'By the breath of God they perish, and by the blast of his anger [عף] they are consumed [כלה]' (v. 9). The psalmist uses similar imagery: 'For we are consumed [כלה] by your anger [אף]' (Ps. 90.7). Once again, this pair of terms is somewhat common, occurring fifteen times in the Hebrew Bible, but combined with Eliphaz's use of another pair of terms from Ps. 90 in the verse before, they create a much closer lexical connection between the two texts. These four words, gathered closely in both contexts, only appear together in one other entire chapter, Isa. 10.

If Eliphaz is referring to the psalm, he has subtly manipulated its message to his purpose. Whereas in the psalm, the collective people of God are speaking in the first-person plural, Eliphaz declares that only the wicked, whom he describes in the third person, excluding himself, suffer this affliction. In true sapiential fashion, Eliphaz splits the world in two between the blessed righteous and the cursed wicked, and, unlike the psalmist, puts himself in the former category. He hopes Job will trust God and do the same (cf. Job 4.5-6; 5.8-27).

Eliphaz continues his speech with a message received from a supernatural visitor: 'Can mortals be righteous before God? Can human beings be pure before their Maker?' (4.17). To support this doctrine of human depravity, Eliphaz's message moves from morality to mortality and claims that even if God charges 'his servants' (עבדיו) and angels with error (v. 18), then those who dwell in houses of clay, have their foundation in the 'dust' (עפר), are 'crushed [דכא] like a moth', and destroyed 'between morning [בקר] and evening [ערב]' can

\footnotetext{
${ }^{48}$ See Goldingay, Psalms, III, p. 30.
} 
hardly hope to escape divine indictment (vv. 19-20). The message concludes with these unfortunate mortals dying 'devoid of wisdom [חכמה]' (v. 21).

These verses combine several significant words from the psalm with its distinctive logical ligature of morality with mortality. First, though the parallel with 'angels' and the contrast with mortals that follows suggests that the 'servants' Eliphaz refers to are heavenly beings (cf. Job 15.15), the repetition of the distinctive use of 'servants' (עבדים) with a pronoun referring to God in the psalm (vv. 13, 16) strengthens his argument because the psalm affirms that even God's servants are liable to divine wrath. ${ }^{49}$ Second, the word the psalm uses for 'dust', דכא, in v. 3 comes from the same rare root Eliphaz uses in v. 19 after referring to 'dust' with the more common word עפר. Although Eliphaz does not mention divine agency explicitly, this word likely suggests the same destructive power it conveyed in the psalm. ${ }^{50}$ Third, like the psalm, where humans are described as flourishing in the 'morning' (בקר) and fading and withering in the 'evening' (ערב) (vv. 5-6), Eliphaz similarly describes human life in the course of a single day, between 'morning' (בקר) and 'evening' (ערב) (v. 20). ${ }^{51}$ Though

${ }^{49}$ For the significance of this term in the psalm, see Hans-Peter Müller, 'Der 90. Psalm: ein Paradigma exegetischer Aufgaben', Zeitschrift für Theologie und Kirche 81 (1984), p. 268; Tate, Psalms, pp. 437-38; Forster, Vergänglichkeitsmotiv, p. 159.

${ }^{50}$ The meaning of ידכאום here is difficult to decipher. Choon-Leong Seow uses the related noun in Ps. 90.3 to support his translation, 'they may be crushed' (Job 1-21, p. 406).

${ }^{51}$ See, e.g., Fohrer, Hiob, p. 145; Friedrich Horst, Hiob 1-19 (BKAT, 16/1; Neukirchen-Vluyn: Neukirchener, 1968), p. 77; Marvin H. Pope, Job (AB, 15; Garden City, NY: Doubleday, 3rd edn, 1973), p. 39; Norman C. Habel, The Book of Job: A Commentary (OTL; Philadelphia: Westminster Press, 1985), p. 130. 
this word pair is common, only in these two passages does it describe life's duration. Finally, Eliphaz's conclusion declares the 'wisdom' (חכמה) desired in Ps. 90 (v. 12) unattainable for these ephemeral mortals. ${ }^{52}$

Some consider the shift in emphasis from morality in vv. 17-18 to mortality in vv. 19-21 in Eliphaz's vision illogical, but the interweaving of these two themes in Ps. 90, which presents the brevity of life as the effect of moral impurity (vv. 7-10), would explain why in Eliphaz's argument 'the fragility and mortality of human beings seems some kind of evidence for their lack of moral reliability'. ${ }^{53}$ Eliphaz's maiore ad minus argument in v. 18-19 would then hinge on the fact that the heavenly beings were not subject to mortality. If God considers even these eternal beings impure, he certainly considers guilty those humans who evidence their impurity in their transience. This resolution of interpretive confusion is strong evidence for an allusion since markers of an intertext are 'both the problem, when seen from the text, and the solution when their other, intertextual side is revealed. ${ }^{54}$ The rare connection of these ideas is in the Hebrew Bible provides further evidence that the Job poet has Ps. 90 in mind. ${ }^{55}$

\footnotetext{
${ }^{52}$ See Horst, Hiob, p. 77.

${ }^{53}$ David J. A. Clines, Job (3 vols.; WBC, 17-18B; Nashville: Thomas Nelson, 1989),
} I, pp. 133-34.

${ }^{54}$ M. Riffaterre, 'Compulsory Reader Response: The Intertextual Drive', in M. Worton and J. Still (eds.), Intertextuality: Theories and Practices (Manchester: Manchester University Press, 1991), p. 58.

${ }^{55}$ For this uncommon connection, see Carol A. Newsom, 'The Book of Job', in $1 \& 2$ Maccabees, Introduction to Hebrew Poetry, Job, Psalms (NIB, 4; Nashville: Abingdon, 1996), p. 378. 
A few verses later, Eliphaz says, 'For misery does not come from the earth, nor does trouble sprout from the ground; but human beings are born to trouble just as sparks fly upward' (5.6-7). Here, he repeats the pair 'misery' (עון) and 'trouble' (עמל) from Ps. 90.10 (cf. 4.8). ${ }^{56} \mathrm{He}$ also uses the word which concludes that verse, עוף ('fly'), as the psalmist writes of humankind's limited days: 'they are soon gone, and we fly away [ונעפה].'

These words reinforce Eliphaz's allusion to the psalm, but they also appear to contradict his earlier statement that humans reap the trouble they sow (4.8), both because here misery and trouble do not sprout from the earth, as his agricultural metaphor suggested and because the passive form of ילד ('born') in v. 7 lightens the load of human responsibility. Interpreters have suggested several emendations to bring the two texts into line. ${ }^{57}$ However, in light of the context of Eliphaz's curse of the fool (5.3) and the possible allusion to the curse motif in Gen. $3.17-19$ here, ${ }^{58}$ the contrast between the agricultural images in 5.6 and 4.8 is best understood as a claim that affliction and trouble do not sprout from the ground spontaneously, but as the result of the plowing and sowing of wickedness Eliphaz described earlier

${ }^{56}$ Both Chrysostom and Luther remark on the common characterization of life as 'toil' and 'trouble' in Job 5.6-7 and Ps. 90.10 (Martin Luther, Luther's Works [55 vols.; St. Louis: Concordia Publishing House, 1955], XIII, p. 123; John Chrysostom, Kommentar zu Hiob [Patristische Texte und Studien, 35; Berlin: de Gruyter, 1990], p. 70).

${ }^{57}$ See Clines, Job, I, pp. 141-42.

${ }^{58}$ Note the repetition of 'human beings' (אדם), 'soil' (אדמה), 'dust' (עפר), and 'sprout' (יצא). See, e.g., Pope, Job, p. 42; Clines, Job, I, p. 141; Leo G. Perdue, Wisdom in Revolt: Metaphorical Theology in the Book of Job (JSOTSup, 112; Sheffield: Almond Press, 1991), p. 119. 
(4.8) and that the fool embodies (5.2-5). This reading brings these verses into agreement with the rest of Eliphaz's speech and also continues his interpretation of the psalm, which may similarly allude to Gen. 3.17-19. ${ }^{59}$ In order to move Job from complaint to confession, he has taken the ambiguous relation of $\sin$ and trouble in Ps. 90 and emphasized human culpability as its cause.

Bildad (ch. 8)

Following Eliphaz's lead, Bildad and also applies the psalm's destructive imagery solely to the wicked. He suggests that Job 'inquire now of bygone generations [דר]' (8.8). Those past generations may have known God to be a refuge in the psalm (Ps. 90.1), but even a thousand years pass like 'yesterday' (אתמis) in God's sight (Ps. 90.4), and, thus, Bildad claims that the ancestors have found that 'we are but of yesterday [תמול]]' (8.9) ${ }^{60} \mathrm{He}$ then launches into an extended plant analogy (vv. 11-22), drawing on the imagery of Ps. 90.5-6. Whereas the psalmist describes an unspecified 'them' as 'grass' (חציר) that flowers and is renewed before it fades and 'withers' (יבשש), Bildad limits the metaphor, only describing 'all who forget God' (v. 13) as 'grass' (חציר) that 'withers' (יבשי) (v. 12). Like the plant, Bildad declares, 'the hope of the godless shall perish' (v. 13).

Job (ch. 14)

With his opening words, 'A mortal [אדם], born of woman, few of days and full of trouble [רגז]' (14.1), Job, by using the word אדם, 'for the first time has projected his own experience

\footnotetext{
${ }^{59}$ See p. 11 above.

${ }^{60}$ See Abelava, Psaume 90, p. 242.
} 
onto the wider canvas of all humanity. ${ }^{61}$ As these words express that 'even the longest life is all too brief' (cf. Ps. 90.9-10), ${ }^{62}$ they also suggest Ps. 90 as a subtext for Job's speech. ${ }^{63}$ In so doing, Job repeats a technique he employed in ch. 10, which returns repeatedly to imagery from Ps. 139, and in 12.13-25, which draws throughout on Ps. $107 .{ }^{64}$

In v. 2, Job continues to engage with Ps. $90,{ }^{65}$ taking up the psalm's description of human transience with the analogy of floral ephemerality. This comparison, which has already appeared in Job 8.11-22, is repeated several other times in the Hebrew Bible, where it serves as a common formula, which makes a direct literary relationship between the two texts difficult to establish. Humanity is compared to plants in sixteen passages, eleven of which describe them as fading or withering. ${ }^{66}$ However, this image's formulaic use does not necessarily mean that the Job poet did not have the particular instance of that formula in Ps. 90 in mind when he wrote Job $14 .{ }^{67}$ Beyond their subject matter, the two texts share the rare word מלל ('fade' or 'wither'), which only appears six times in the Hebrew Bible with this

\footnotetext{
${ }^{61}$ Clines, Job, I, pp. 288, 324. Similarly, Fohrer, Hiob, p. 254.

${ }^{62}$ Pope, Job, p. 106.

${ }^{63}$ Abelava, Psaume 90, pp. 242-43. He notes the parallel between Job 14.1 and Ps.
} 90.10.

\footnotetext{
${ }^{64}$ See Kynes, My Psalm, pp. 89-91, 108-12.

${ }^{65}$ Abelava, Psaume 90, p. 243.

${ }^{66}$ Pss. 37.2; 90.5-6; 92.8; 102.12; 103.15-16; 129.6; 2 Kgs. 19.26; Isa. 37.27; 40.8;
}

Job 8.12; 14.2. See Urbrock, 'Mortal and Miserable Man', pp. 1-23.

${ }^{67}$ See p. 5 above. 
meaning. ${ }^{68}$ Job 14.2 also uses a word for 'flower' (ציץ) that comes from the same root as the the verb 'to flourish' (צוץ) in Ps. 90.6. The combination of מלל with either word is unique in the Hebrew Bible.

This verse introduces another subtext, Job's response to his friends' interpretation of the psalm. The shared use of the word יצא 'goes forth' to describe the blossoming of a plant (cf. Job 8.16) suggests that Job is countering Bildad's plant analogy. ${ }^{69}$ Job takes different words from the floral analogy of Ps. 90.5-6 so that between him and Bildad there is a nearly comprehensive allusion to the plant imagery in the psalm (see p. 27 below). Job's use of this imagery differs from Bildad's, though, because he does not present human ephemerality in the context of a contrast between the righteous and the wicked (cf. Job 8.13). In contrast to Bildad, as well as Eliphaz (Job 4-5), Job claims all are subject to this fate. Questioning God in the following verse - 'Do you fix your eyes on such a one? Do you bring me into judgment with you?' (14.3) — the righteous Job takes the brevity of life motif from the previous verses, which often grounds a call for mercy (cf. Ps. 103.13-14; Ps. 90), challenges Bildad's retributive interpretation of it, ${ }^{70}$ and turns it into a reproach against God. ${ }^{71}$

Job continues this indictment in the next verse, which commentators have found 'extremely difficult to interpret in context. ${ }^{72} \mathrm{He}$ turns from Bildad to Eliphaz, with a 'virtual
${ }^{68}$ See Gordis, Job, p. 147.
${ }^{69}$ Habel, Job, p. 240.
${ }^{70}$ See John E. Hartley, The Book of Job (NICOT; Grand Rapids, MI: Eerdmans, 1988), p. 231.

\footnotetext{
${ }^{71}$ Fohrer, Hiob, p. 255; cf. Perdue, Wisdom in Revolt, pp. 156-7 n. 2.

${ }^{72}$ Gordis, Job, p. 147.
} 
quotation' of the supernatural message he received that no one can be 'pure' (טהר) before God (Job 14.4; cf. 4.17). ${ }^{73}$ Like Eliphaz, he then moves from morality to mortality by resuming the theme of life's brevity from vv. 1-2, here stressing its fixed limits. Clines observes that one of the difficulties facing interpreters of v. 4 is that in the rest of this strophe (vv. 1-6), Job is addressing life's brevity, not its uncleanness. ${ }^{74}$ However, as in 4.17-21, Job's reasoning becomes clearer in light of the relationship between these ideas in Ps. 90. The fixed number of days humans receive (14.5) is reminiscent of Ps. $90.10 .^{75}$ It grounds Job's demand that God turn away his piercing gaze (cf. 14.3; Ps. 90.8) from short-lived humanity so that they 'may enjoy [רצא], like laborers, their days [יומו]' (v. 6), which resonates with the psalmist's desire 'that we may rejoice [רנן] and be glad [שמשח] all our days [ימינו]' (Ps. 90.14). Job thereby appeals to the human transience motif's other function in the psalm, as a cause for divine mercy. ${ }^{76}$ Though humans may be unclean, Job longs for more proportional divine treatment (cf. Ps. 90.15).

Returning to this motif inspires an extended treatment of the plant analogy from v. 2, Bildad's earlier speech, ${ }^{77}$ and Ps. 90.5-6. Job repeats the word 'shoots' (יוֹנקת) in v. 7 that appears in 8.16 and only four other places in the Hebrew Bible. ${ }^{78}$ He claims that the tree has 'hope' (תקוה; cf. Job 8.13) that 'if it is cut down, that it will sprout [חלף] again' (v. 7), repeat-

${ }^{73}$ Ibid..

${ }^{74}$ Clines, Job, I, p. 325.

${ }^{75}$ Habel, Job, p. 240; Hartley, Job, p. 232.

${ }^{76}$ See Abelava, Psaume 90, p. 253.

${ }^{77}$ J. Gerald Janzen, Job (Interpretation; Atlanta: John Knox Press, 1985), p. 108.

${ }^{78}$ See Habel, Job, p. 177. 
ing the word used twice for the sprouting of grass in Ps. 90.5-6, the only other place in the Hebrew Bible where it describes a plant's renewal. ${ }^{79}$ This word then returns in noun form as Job wonders whether mortals, like the tree, have any hope of 'renewal' (חליפת; v. 14).

Job seems to have rejected that possibility already in the preceding verses, however. Mortals, he argues, are not like a dead tree that may bud again at the scent of water (vv. 8-9) but like the waters of a lake or river that 'dry up' (יבש: v. 11; cf. Ps. 90.6). The figure of the tree belies a 'bitter irony'; what at first appears to be a symbol of hope only confirms Job's despair. ${ }^{80}$ When humans lie down, they will never be roused from their 'sleep' (שנה; v. 12).

${ }^{79}$ For this shared use of חלף, though in the hiphil in Job and the qal in the psalm, see Franz Delitzsch, Das Buch Iob (Leipzig: Dörfling \& Franke, 1864), p. 140; Gordis, Job, p. 148; Clines, Job, I, p. 28.

${ }^{80}$ Newsom, 'Job', p. 441. Similarly, Horst, Hiob, p. 187. 
This word similarly appears as a metaphor for death in Ps. 90.5, ${ }^{81}$ a second of the mere four times this metaphor is used in the Hebrew Bible (cf. Jer 51.39, 57). ${ }^{82}$

Yet, amidst this despondence, Job's faith resurfaces. Job's flight of hope in v. 13 involves a desire for God’s 'wrath' (אר, cf. Ps. 90.7, 11) to 'pass' or ‘turn’ (שוב) similar to the psalmist's turn to hope in Ps. 90.13, where he demands that God 'turn' (שוב). Further, just as the psalmist asks, 'How long?' in that verse, so Job longs for God to set a time to remember him. Like the psalmist, he acknowledges both that God's wrath is the cause of his suffering and that God alone is his hope of escape. For the first time, the possibility that God's present hostility toward him might be replaced by a more positive attitude appears explicitly in the text, as Job envisions 'a God beyond the God he is now experiencing' ${ }^{83}$

${ }^{81}$ Ps. 90.5-6 involves a number of interpretive difficulties, which have inspired several proposed emendations and varying translations, including that this word is actually שָָָׁה ('year') (see Kraus, Psalms, p. 213). For further discussion of these verses, see N. H. TurSinai, 'Unverstandene Bibelworte I', VT 1 (1951), pp. 307-9; G. R. Driver, 'Old Problems

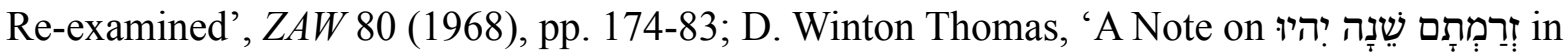
Psalm XC 5', VT 18 (1968), pp. 267-68; Charles F. Whitley, 'The Text of Psalm 90:5', Biblica 63 (1982), pp. 555-57; Matitiahu Tsevat, 'Psalm XC 5-6', VT 35 (1985), pp. 115-17; Thijs Booij, 'Psalm 90:5-6: Junction of Two Traditional Motifs', Biblica 68 (1987), pp. 393-96. I side with Zenger, who claims no emendation is necessary (Hossfeld and Zenger, Psalms 2, p. 417).

${ }^{82}$ For this similarity, see Fohrer, Hiob, p. 257; Tate, Psalms, p. 434.

${ }^{83}$ Clines, Job, I, p. 330. 
Though Job proceeds to imagine open communication with God, the deity longing for him as the 'work of [God's] hands' (v. 15; cf. Ps. 90.17), and freedom from God's inquistorial gaze upon his sin and 'iniquity’ (עון) (vv. 16-17; cf. Ps. 90.8), these dreams soon plunge into pessimism. Job returns once more to life's brevity in vv. 18-19, choosing as 'the climactic symbol of the transitory', the mountain and the rock, which both serve as 'traditional metaphors for eternal stability' (e.g., Gen. 49.26). ${ }^{84}$ In Ps. 90, God's existence 'before the mountains [הר] were brought forth and the earth [ארץ] and world [תבל] were formed' demonstrates the deity's eternal constancy (v. 2). Job claims that even the 'mountain' (הר) 'crumbles' (נבל) and the torrents 'wash away' (שטר) the soil of the 'earth' (ארץ). Though הרץ and נבל commonly appear in close proximity, the verb wh resonates aurally with 'world' (תבל) in the psalm, creates a closer connection, which is reinforced thematically by Job's literary erosion of the analogy of stability on which the psalmist builds his hope in God. Further, נבל generally has a floral subject (cf. Pss. 1.3; 37.2), and thus suggests a further 'veiled allusion' to the opening analogy from nature in Job $14.2,{ }^{85}$ and thus also Ps. $90.5-6 .{ }^{86}$ As even the mountains and earth may dematerialize, so, Job accuses God, 'You destroy [אבד] the hope [תקוה] of mortals' (v. 19). In so doing, Job responds to Bildad's contention that 'the hope

\footnotetext{
${ }^{84}$ Habel, Job, p. 244.

${ }^{85}$ Ibid.
}

${ }^{86}$ Though the verb שטטף differs from the one used in Ps. 90.5 (זרם), the two texts also share the imagery of a flood's destructive power. For זרם as 'pour out/flood/ejaculate', see Tate, Psalms, p. 433. 
[תקוה] of the godless shall perish [אבד]' (8.13) by claiming that all humanity and not merely the wicked suffer God's chastening. ${ }^{87}$

By the end of ch. 14, the floral analogy for human transience in Ps. 90.5-6 has clearly become central to the debate. Nearly every word from these verses appears in the dialogue, all in similar reflections on human transience. ${ }^{88}$

Ps. 90.5-6

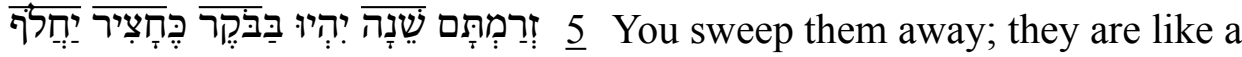
dream, like grass that is renewed in the morning;

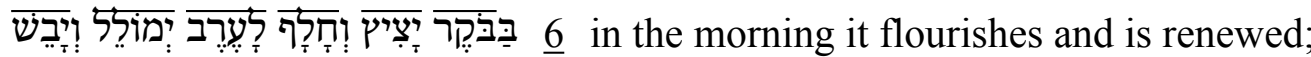
in the evening it fades and withers.

Job 4.20

Between morning and evening they are destroyed; they perish forever without any regarding it.

Job 8.12

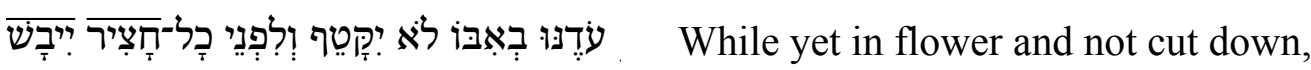
they wither before any other plant.

Job 14

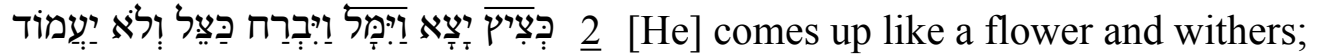
flees like a shadow and does not last...

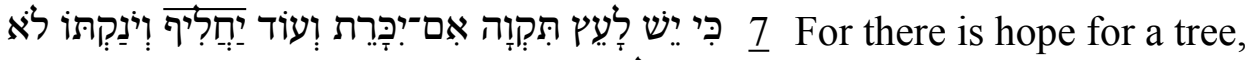

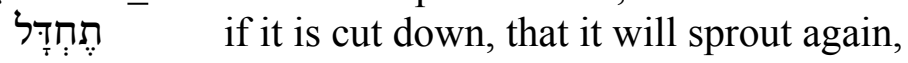
and that its shoots will not cease...

${ }^{87}$ Bildad appears to recognize Job's challenge and respond in his next speech. Addressing Job's interpretation of the psalm, he asks whether 'the rock be removed out its place' (ויעתק צור ממקמו) because of Job (Job 18.4), alluding to Job's questioning of the psalmist's praise of divine stability: וצור יעתק ממקמו (Job 14.18-19; cf. Ps. 90.2).

${ }^{88}$ A similar distributive allusion appears in the friends' allusions to Ps. 8.4 [3] mentioned above. The psalmist considers the 'heavens' (שמים), the 'moon' (ירח), and the 'stars' (כוכבים), while Eliphaz mentions the first of those words and Bildad the latter two. 
so mortals lie down and do not rise again;

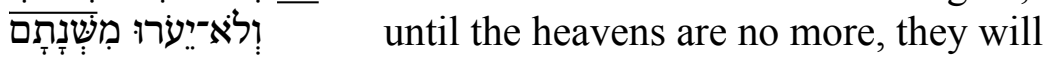
not awake or be roused out of their sleep.

The shared words are either rare, used in a similarly distinctive way, or paired together in uncommon ways. Even though the comparison of humanity to a withering plant appears several times in the Hebrew Bible, this verbal repetition in a similar thematic context provides, at least, strongly suggestive evidence that the author of Job had the specific use of that imagery in Ps. 90.5-6 in mind when writing Job. 'Allusions often radiate out to contiguous allusions' ${ }^{89}$ and this happens throughout the dialogue as allusions to other aspects of the psalm draw its broader context into the debate.

Eliphaz (ch. 15)

Thus, in the following chapters, the friends seem to recognize Job's rejoinders and retort with further allusions. If Job is alluding to Ps. 90.2 in 14.18-19, Eliphaz responds ten verses later (15.7). ${ }^{90}$ Eliphaz conflates Ps. 90.2 with Prov. 8.25 to put Job in his place..$^{91}$

${ }^{89}$ Robert Alter, The Pleasures of Reading in an Ideological Age (New York: Norton, 1996), p. 118.

${ }^{90}$ For the connection between Ps. 90.2 and Job 15.7, see, e.g., Fohrer, Hiob, p. 269; Horst, Hiob, p. 223; Habel, Job, p. 253; Clines, Job, I, p. 350.

${ }^{91}$ The dialogue's intratextual allusions demonstrate conflation to be amongst the author's allusive techniques. See, e.g., Bildad's conflation in 25.4 of Job's question from 9.2 with Eliphaz's from 15.14 in order to refute his complaint (Kynes, My Psalm, p. 48). For the author's conflation of passages from elsewhere in the Hebrew Bible, see Leslie S. Wilson, The Book of Job: Judaism in the 2nd Century BCE: An Intertextual Reading (Studies in Judaism; Lanham, MD: University Press of America, 2006), p. 5 n. 4. This technique is also 
Ps. 90.2

\author{
Before the mountains were brought forth,

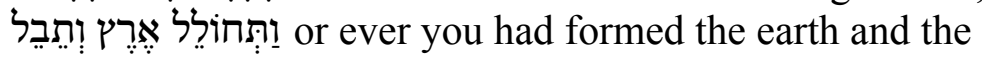

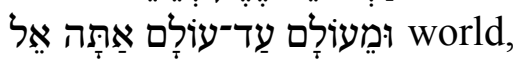 \\ from everlasting to everlasting you are God. \\ Prov. 8.25 \\ Before the mountains had been shaped, \\ before the hills, I was brought forth.
}

Job 15.7

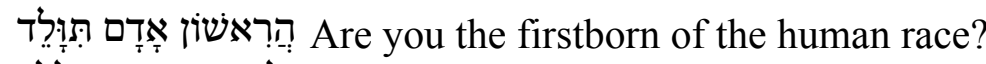
Were you brought forth before the hills?

The exact repetition of the phrase uniquely shared by Prov. $8.25 \mathrm{~b}$ and Job $15.7 \mathrm{~b}$ in the Hebrew Bible strongly indicates dependence, and Eliphaz's use of the phrase as an accusatory question leaves 'little doubt' that the text in Proverbs came first (whether or not the Job poet encountered it as a separate poem before its placement there).$^{92}$ The lexical and thematic similarity between Ps. 90.2a and Prov. 8.25a also suggests dependence. Whichever of those texts is alluding to the other, ${ }^{93}$ potentially inspired by this connection, the Job poet, who has demonstrated familiarity with Ps. 90 elsewhere and has repeated a word, ילד ('to give birth'), in the psalm and not in Prov. 8.25 in the same position, appears to allude to them both.

If so, then Eliphaz's allusion combines both texts into a double-edged attack on Job. Francis Andersen argues that Eliphaz alludes to 'the same idea...found in Psalm 90.2' to

employed in the Qumran Hodayot (Svend Holm-Nielsen, Hodayot: Psalms from Qumran

[Acta Theologica Danica, 2; Aarhus: Universitetsforlaget, 1960], p. 315).

${ }^{92}$ Clines, Job, I, p. 350.

${ }^{93}$ For Proverbs as the later text, see Michael V. Fox, Proverbs $1-9$ (AB, 18A; New York: Doubleday, 2000), p. 284. 
charge Job with comparing himself with God. ${ }^{94}$ Robert Gordis, however, claims that Eliphaz employs language 'identical' to Prov. $8.25 \mathrm{~b}$ to ask Job, in effect, 'Are you Wisdom personified? ${ }^{95}$ By conflating these verses, Eliphaz accuses Job of thinking himself as great as both God, or at least a semi-divine figure, and Wisdom. Hinting at these allusions, both the words 'God' (אלוה) and 'wisdom' (חכמה) appear in the following verse: 'Have you listened in the council of God? And do you limit wisdom to yourself?' (Job 15.8). ${ }^{96}$

Bildad (ch. 18)

Bildad, the next friend to speak, draws again on the disputed floral trope from the psalm in a extended description of the fate of the wicked (18.5-21). He claims of the wicked, 'Their roots [שרשש]] dry up [יבשיר] beneath, and their branches [קציר] wither [מלל] above' (v. 16). Recalling the tree imagery of 'roots' (שרש) and 'branches' (קציר) with which Job elaborated

${ }^{94}$ Francis I. Andersen, Job (London: Inter-Varsity Press, 1976), pp. 176-77. Many see a reference to the tradition of primal man in Job 15.7 (e.g. Fohrer, Hiob, p. 268; Clines, Job, I, p. 349; Seow, Job 1-21, pp. 700-1). However, likely influenced by Isa. 41.4; 44.6; 48.12, Andersen claims 'First' is a name for God 'in view of Ps 90:2' (Andersen, Job, p. 176 n. 4). Either way, Eliphaz is charging Job with assuming at least superhuman if not semi-divine status.

${ }^{95}$ Gordis, Job, p. 161.

${ }^{96}$ At the end of his speech, Eliphaz repeats the image of God destroying the wicked with the blast of his breath from 4.9, but now draws on a word (יבשי) and the floral imagery from Ps. 90.6 rather than the 'consuming anger' of Ps. 90.7: 'heat will dry up [יבש] his shoot [ינקת], and he will be removed by the wind [רוח] of his mouth' (15:30). This is Seow's translation, following the MT rather than the OG as in the NRSV (Job 1-21, pp. 696, 724). 
on the psalmist's similitude in 14.8-9 and two words from Ps. 90.6, מלל a יבש, he reasserts his application of the psalmic analogy exclusively to the wicked in contrast to Job's generalization in ch. 14.

\section{Holistic Interpretation}

Tracing the contribution of allusions to Ps. 90 to the debate between Job and his friends underscores the theological crux of their dispute. Franz Delitzsch characterizes the dialogue as a conflict between two visions of God: 'Die Freunde denken sich Gott als den Absoluten der nur nach Gerechtigkeit, und Iob [sic] denkt ihn sich als den Absoluten, der nach der Willkür seiner Machtvollkommenheit handelt. ${ }^{97}$ Neither, Delitzsch claims, fully represents the God of the Hebrew Bible; the friends are dogmatically one-sided, while Job's suffering distorts his perception. Eliphaz and Bildad appeal to the psalm's depiction of divine judgment to support their belief that the absolutely just God only destroys the wicked. They therefore transform the ground for the psalmist's petition into an attempt to silence complaint. In ch. 14, however, Job proclaims that God's apparently arbitrary destructive power extends to all humanity, including a righteous man such as himself (14.3). He uses the psalm's imagery in a similar context of lament, but, rather than proceeding to hopeful petition as the psalmist does (Ps. 90.13-17), his brief foray into hypothetical hope (14.14-17) is swallowed up in despair (14.18-22). The author of Job appears to have recognized the tension in Ps. 90 between its possible specific or universal referent. ${ }^{98}$ Emphasizing the dismal universal fate of humanity,

\footnotetext{
${ }^{97}$ Delitzsch, Das Buch Iob, p. 148.

${ }^{98}$ Westermann notes a parallel between the psalm and Job's expansion of his personal
} suffering into contemplation of human destiny ('Der 90. Psalm', p. 346). 
Job both accuses God and defends himself against his friends, who associate him specifically with the wicked due to his suffering.

The friends do not present God's actions as exclusively punitive, however. In 5.8-27, for example, Eliphaz promises Job divine deliverance if he seeks God (v. 8). Likewise, Bildad appears to present the prosperity of the righteous alongside the destruction of the wicked in his extended botanical analogy (8.16-19). ${ }^{99}$ By contrast, though Job grasps at hope in 14.13-17, his hopes are crushed (14.19). In the tension between deliverer and destroyer in the psalm, the friends appear to maintain both aspects, while Job holds merely to the latter.

Like the psalmist, however, Job employs the imagery of human transience to ground his appeal for a transformed divine countenance toward him $(14.3,6,13,15-16$; cf. Ps. 90.8, 13). Because human days are numbered, Job argues, God should desist so that they may enjoy those days (14.5-6; cf. Ps. 90.10, 14). The comparison of human mortality with the tree's hope for renewal in 14.7-12 accentuates this point. Unlike trees, humans are doomed to die and not rise again; all the more reason for God to pity them in their limited lifetimes. Job's question in v. 14 would then be more a rhetorical exclamation point than a theological speculation: 'If mortals die, will they live again?'

The flight of hope which follows this question (vv. 14-17) may seem short lived, as Job quickly accuses God of destroying humanity's hope (v. 19). However, the imagery of crumbling mountains and a flooded earth provides a subtle clue that this hope is not extinguished. If Job is indeed alluding to those images from the psalm's first two verses, he has appealed to the same promises which gave that community hope. As in his parody of Ps. 8, Job's reversal of those images could be a skeptical rejection of the divine refuge they describe, but it would serve his interests better if it were a faithful attempt to get God's atten-

\footnotetext{
${ }^{99}$ See Gordis, Job, p. 521.
} 
tion, to attempt to hold the deity to those promises just as the psalmist had so that God might again care for 'the work of his hands' (v. 15; cf. Ps. 90.17). In this, it appears Job is successful, earning in the epilogue an additional 140 years of life, twice the normal lifespan in Ps. $90.10 .^{100}$

Job's use of the transience trope in ch. 14 to charge God with the destruction of hope would, however, offer the psalmist scant support for his expectation of deliverance. Unlike Job, who is able to play off the affirmation of God as a refuge which opens the psalm and the confident requests which conclude it, the psalmist would find little in the repeated use of the brevity of life motif in Job as a whole to ground his community's hope. To make anything of the friends' association of mortality with wickedness, he would need to appeal to the righteousness of his community to justify God's mercy instead of confessing their iniquities (Ps. 90.8). Further, the way the psalmic imagery, especially the floral analogy, is split between Job and the friends, with each using different lexical aspects, provides an additional indication that the Job poet is alluding to the psalm. Reading these as allusions to Job would require the reader of Ps. 90 to incorporate the divergent purposes to which Job and the friends put this imagery. Though evidence is lacking to determine the date of either text absolutely, this evidence strongly suggests Job is later than the psalm.

\section{Conclusion}

This does not mean, however, that identifying these allusions only clarifies the meaning of Job. Like other aggadic exegesis, the book of Job 'draws forth latent and unsuspected meanings' from Ps. $90 .^{101}$ The allusions to this psalm function like the dialogical interpreta-

\footnotetext{
${ }^{100}$ Clines, Job, III, p. 1239.

${ }^{101}$ Fishbane, Biblical Interpretation, p. 283.
} 
tion of other psalms, as both Job and his friends find support for their interpretations of Job's suffering in the psalm's struggles with the various tensions of human relationship with God. Job's friends present suffering as specific to sinners, while Job depicts it as the universal destiny of humankind. The friends present God as both deliverer and destroyer, but only to justify the deity's destruction of Job; Job presents God as a destroyer in order to entreat God to deliver. The friends posit the brevity of life as an effect of human sin to motivate Job to repent while Job uses it to ground his argument against God and move the deity to mercy. ${ }^{102}$

Like Ps. 90, Job maintains that true faith does not surrender to passive resignation, but courageously enters into confrontation with God. ${ }^{103}$ Participating in a broader move toward the 'scripturalization' of prayer in the Second Temple period, ${ }^{104}$ Job drew on the psalm itself to strengthen his case. Paradoxically, the authoritative status texts like this were acquiring made their meaning all the more liable to debate and disagreement, as the Midrash later demonstrates. The author of Job depicts this developing interpretive tendency as well. His dialogical interpretation highlights the possibilities for making meaning out of and finding hope in Ps. 90.

${ }^{102}$ See Urbrock, 'Mortal and Miserable Man', I, pp. 4-5.

${ }^{103}$ Abelava, Psaume 90, p. 243.

${ }^{104}$ Judith H. Newman, Praying by the Book: The Scripturalization of Prayer in Second Temple Judaism (SBLEJL, 14; Atlanta: Scholars Press, 1999), pp. 12-13. 